\title{
REALITY AS ARTIFACT: FROM FEIST TO FAIR USE
}

\author{
WENDY J. GORDON*
}

\section{INTRODUCTION}

Lawyers more than most people should be aware that what language calls "facts" are not necessarily equivalent to things that exist in the world. After all, when in ordinary conversation someone says "it's a fact that $X$ happened," the speaker usually means, "I believe the thing I describe has happened in the world." But when a litigator presents something as a "fact," she often means only that a good faith argument can be made on behalf of its existence. Two sets of factfinders can look at the same event and come to diametrically opposed conclusions-each of which is binding, but on different people. ${ }^{1}$ Most law students come to accept these disturbing phenomena as limitations inherent in an adversary system of justice. ${ }^{2}$ Yet lawyers have not yet accepted that all investigative efforts are similarly limited by observers' expertise, viewpoints, and tools. A Justice on the United States Supreme Court recently announced, pointing to the census as an example, that facts such as population density cannot be "created," 3 and then used that assumption to deny copyright protection to inhabitant lists on the ground that facts are only

Copyright $\odot 1992$ by Wendy J. Gordon

* Professor of Law, Rutgers University School of Law-Newark; Visiting Professor of Law, University of Chicago School of Law.

I thank the S.I. Newhouse Faculty Research Fund of Rutgers Law School for supporting the preliminary work leading to this article. Early versions of the paper were presented at the "Conference on Intellectual Property and the Construction of Authorship" held at Case Western Reserve University, and to the Law and Humanities Institute of New York City; I am grateful to the participants at both venues for their comments, and to Sam Postbrief, Jim Lindgren, and Jeff Sherman for theirs.

1. In first year courses, law students are usually introduced to this odd phenomenon through a pair of cases arising out of an oil spill and subsequent fire. In both cases the question was whether a reasonable man could have foreseen that the oil could ignite when spread on water. In the first case, the dispute was between two parties each of whom would have been hurt by such a finding; not surprisingly, after listening to the parties' witnesses (including a noted expert), the court concluded that fire on the oily water was unforeseeable. Overseas Tankship (U.K.) Ltd. v Morts Dock E Engineering Co., Ltd. (The Wagon Mound), 1 All Eng Rep 404, 415 (Privy Council 1961). The second Wagon Mound case included a party who would have been helped rather than hurt by a finding of foreseeability. This time, an equally objective finder of fact came to the conclusion that a slight danger of fire could have been foreseen. Overseas Tankship (U.K.) Ltd. v Miller Steamship Co. (The Wagon Mound No. 2), 2 All Eng Rep 709, 718 (Privy Council 1966).

2. Note, however, that the collateral estoppel doctrine often prevents relitigation of facts.

3. Feist Publications Inc. v Rural Telephone, 111 S Ct 1282, 1288-89 (1991) (O'Connor for a unanimous court). 
"discovered" rather than "authored."4 This was, of course, the famous Feist case, in which the Supreme Court denied copyright to the white pages of a Kansas telephone book. ${ }^{5}$ Though I entirely concur with the denial of copyright, the opinion's reasoning is deeply flawed. The opinion reads as if the Supreme Court distinguished two sorts of facts-Facts 1 that are "out there in the world"6 and Facts 2 that are human attempts to depict Facts denied copyright in lists of Facts 2 on the ground that Facts 1 and Facts 2 were the same. We academics may or may not applaud the denial of copyright, but most of us unite in seeing the Court's insistence that facts are never "created" as a conceptual error. ${ }^{7}$ Ironically, the embarrassingly high level of approximation in the United States census ${ }^{8}$ itself should have reminded the judges that any "fact" on the books is in some sense created by people; though the census-taker has not created that which a number seeks to measure, the number he writes on the page has its origin with him. ${ }^{9}$ True, other observers might arrive at the same number, and this consideration is relevant to the policy question of whether the first counter should receive copyright in his number-but this does not make the number on the printed page an uncreated artifact. Ironically, the plaintiff phone company in Feist may even have generated the very phone numbers at issue. ${ }^{10}$

\section{Id.}

5. Id at 1297 (denying copyright to white pages listing Kansas area's inhabitants by name, town, and telephone number).

6. Of course, a skeptic might deny that reality (Fact $\left.)_{1}\right)$ exists independent of perception.

7. See Wendy J. Gordon, On Owning Information: Intellectual Property and the Restitutionary Impulse, $78 \mathrm{Va}$ L Rev 153, 158-60 nn21-22 (1992) (pointing out the conceptual error but agreeing with the Court's result on other grounds); Jessica Litman, The Public Domain, 39 Emory LJ 965, 996-97 (1990) (arguing that facts "do not exist independently of the lenses through which they are viewed"); Jane Ginsburg, Sabotaging and Reconstructing History: A Comment on the Scope of Copyright Protection in Works of History After Hoehling v. Universal City Studios, 29 J Copyright Society of USA 647, 658 (1982) (identifying the "fallacy" in the "Platonic fact precept" that "facts merely exist"); but see Melville B. Nimmer \& David Nimmer, 1 Nimmer on Copyright \&\& 2.03[E] at 2-35 through 2-36, 2.11[A] at 2-156 through 2-159 (1990) ("Nimmer on Copyrighl") (arguing that facts are uncopyrightable because they can only be discovered and not created; relied upon by the Court in Feist).

This issue and related issues continue to be debated on the philosophic level. For a useful introduction, see the discussion of "words and the world" in Hanna Fenichel Pitkin, Wittgenstein and Justice: On the Significance of Ludwig Wittgenstein for Social and Political Thought 99-115 (U Cal Press, 1972). For interdisciplinary perspectives on these issues, see the symposium, Questions of Evidence, appearing at 17 Critical Inquiry 738 (1991) and 18 Critical Inquiry 76 (1991). Also note that just as "fact" may be subject to varied interpretations and definitions, so may "meaning" and "understanding." See May Brodbeck, Meaning and Action, in May Brodbeck, ed, Readings in the Philosophy of the Social Sciences 58-78 (MacMillan, 1968).

8. See, for example, The Uncountables; The Census, 320 Economist A29 (July 20, 1991).

9. The fact that the names, towns, and phone numbers listed in Feist probably required an insignificant amount of intellect to generate might be a separate ground for denying copyright. But the Court's discussion was not limited to such facts; the opinion applies to any bare fact (or any uncreatively arranged and selected list of facts), including those facts that only great experimental ingenuity could bring to light.

10. As a further irony, those phone numbers probably embody consciously chosen patterns, such as the allocation of particular exchanges to geographically contiguous neighbors; a phone number may therefore convey information, such as the locality in which one resides. Such organizational effort-were it to rise above the trivial-could favor a grant of copyright. See Toro Co. $v R$ E $R$ Products Co., 787 F2d 1208, 1213 (2d Cir 1986) (numbering system for lawn-care machine 
Assume for the moment that the Supreme Court had admitted in Feist that facts and created works are not mutually exclusive categories-that Facts san $_{2}$ be "created." 11 Then the Court would have had to deny copyright in lists of Facts $_{2}$ on the basis of straightforward interpretation of congressional policy and statutory language. ${ }^{12}$ The policy dimension of any such argument should focus on the effects of granting ownership in Facts ${ }_{2}$, rather than on the way Facts $_{2}$ come into existence.

Most notably, copyright's long term and comparatively easy-to-obtain grants of protection are based on the premise that nothing of very high value-no idea or fact-is being appropriated by private parties. ${ }^{13}$ Facts $_{2}$ may be creative, as ideas may be, but Congress has determined that giving private ownership in them is simply more costly than society can afford, ${ }^{14}$ or in any event more costly than the copyright balance contemplates. Further, even independent of the language of the copyright statute, the public may have

parts denied copyright on the ground, inter alia, that the numbers were assigned randomly and conveyed no information about "types or categories of parts").

I am grateful here to Douglas Lewis.

11. I do not need to argue that all facts-on-the-page (all Facts ${ }_{2}$ ) are created; rather, my point is made if one agrees that the Supreme Court was wrong to insist that none are created. Indeed, it seems likely that some facts-on-the-page (some Facts ${ }_{2}$ ) are more "created" than others. For an analogous point, see Pitkin, Wittgenstein and Justice at 114 (cited in note 7).

12. It is also possible that the Court could have looked to the constitutional language. Of course, this is an arguably unnecessary step, given the clarity with which the relevant statutory provisions indicate that uncreatively arranged and selected compilations are not entitled to copyright. See 17 USC $\$ \S 101,103$ (1988) (definition of "compilation" and scope of relevant copyright protection). Nevertheless, it is conceivable that the Court might have examined the Constitution's reference to "authors" even if the Court had recognized that those who research and state facts do more than merely uncover reality. But such an inquiry would not alter the conclusions of this article.

Admittedly, "authorship" has some conceptual content. Even if one avoids the Court's flawed distinction between "created" and "discovered" works, one can still differentiate the psychologic and intellectual processes a surveyor uses to measure the height and contours of a cloud-shrouded mountain from the processes an artist employs to draw that mountain. Both sets of processes may involve creativity and ingenuity, but the latter is more "expressive" (in a conventional sense) than the former. In addition, the respective outputs of the two sets of processes-for example, the surveyor's list of numbers and the artist's sketch-also have differences of character. It may be that the Founders had only the latter, expressive processes and products in mind when they authorized the federal government to grant copyrights "to authors." If so, then one reason for refusing to grant copyright in facts might be lack of "authorship." But some clearly authored works-such as the Mount Rushmore sculptures-are also facts of life, and it is these art/facts that the instant article addresses.

Note that a full inquiry into "authorship" will be complex, see, for example, Peter Jaszi, Toward a Theory of Copyright: The Metamorphoses of "Authorship," 1991 Duke L J 455, and not resolvable by a simple definitional inquiry. For example, it is possible that the public's having different needs for matters of "fact" and of "fancy" itself plays into the concept of what it means to be a "writing" of an "author." In addition, note that the statute evidences strong policies independent of the authorship issue that push against allowing the ownership of facts, and Congress is constitutionally free to forbid ownership even of an "authored" artifact.

13. See Gordon, 78 Va L Rev at $159 \mathrm{n} 33$ (cited in note 7)(comparing the costs, benefits, and duration of patents, copyrights, and trademarks).

14. The social cost of ownership in facts is high, but there are also opportunity costs (resulting from dampened incentives) in denying protection. Resolution of the cost question is ultimately a mixed normative and empirical question: what should count as a cost is a normative issue (human frustration? just dollars and cents?), while counting up the costs is an empirical one. 
justifiable claims to copy facts that it does not have regarding other created works. ${ }^{15}$

The presentation of such arguments would have been a significant step forward, for such an approach would have forced the Court to articulate the policy weighings that can affect how the law will treat the range of created works that function as fact. ${ }^{16}$ By instead assuming that created facts simply do not exist, the Court has hobbled judges in their dealings with the many contexts in which the hybrid nature ${ }^{17}$ of created facts causes conceptual and practical difficulties.

This article is concerned with works that do not primarily attempt to reflect the world; they are not Facts 2 seeking to describe Facts 1 . Rather, they are the largely imaginative works-songs, speeches, cartoons, architectural designs, sculptures, stories, letters-in which the depiction of Facts $_{1}$ plays a minor and untroubling role. ${ }^{18}$ These works are problematic when they themselves become facts with which their audiences have to deal.

II

\section{Defining the Problem}

Works of indisputable creativity are used as facts in many contexts. A musicologist might photocopy the score of a pathbreaking symphony for her class to analyze; an angry television evangelist might send his flock reprints of a cartoon that ridicules him in order to rebut the cartoon or arouse support; 19 a satirist might recreate characters from a popular movie she wishes to mock; a legal scholar might quote from a judicial opinion and give the page numbers in a standard reporter system where the quotation can be found; ${ }^{20}$ or a

15. Some commentators seek to base such public entitlements on the first amendment; public entitlements to copy may have other bases as well, including some of the same arguments that are used to justify private property in the first instance. For an example of the latter approach, defending the nonprotectability of classes of facts on the basis of Lockean normative arguments, see Wendy J. Gordon, A Property Right in Self Expression: Equality and Individualism in the Law of Intellectual Property (draft on file with Law Eं Contemporary Problems).

16. It also would have eliminated the preemption problems introduced by the real opinion's odd epistemology. See Gordon, $78 \mathrm{Va} \mathrm{L} \mathrm{Rev} \mathrm{at} \mathrm{158-60} \mathrm{nn21-22} \mathrm{(cited} \mathrm{in} \mathrm{note} \mathrm{7),} \mathrm{and} \mathrm{the} \mathrm{sources} \mathrm{cited}$ therein (discussing whether Feist will affect the extent to which states would be preempted from prohibiting the copying of facts that appear in compilations); Wendy J. Gordon, Toward a Jurisprudence of Benefits: The Norms of Copyright and the Problems of Private Censorship, 57 U Chi L Rev 1009 , 1020-26 (1990) (discussing preemption generally).

17. The "created" aspect of their nature pulls toward protection; the "fact" aspect pulls toward freedom of use.

18. For example, perhaps the song names a city that exists, or the cartoon depicts a face that exists.

19. This example was inspired by Hustler Magazine, Inc. v. Moral Majority, Inc., 796 F2d 1148 (9th Cir 1986) (reproduction by Moral Majority of parody advertisement that appeared in Hustler magazine, held fair use).

20. As with some of the other examples in the text, no special fact-oriented doctrine would be necessary in order to privilege the scholar's use. As for her quoting from an opinion, judicial opinions are generally agreed to be in the public domain; as for the page numbers, either fair use or limitations on the copyright the publisher holds in its compilations would render non-infringing the scholar's provision of page numbers. This example is included because it provides a usefully straightforward illustration of factual use, and because it has a legally troubling cousin in the real 
biographer might print a passage from one of her subject's letters to illustrate an interpretation of the subject's character. In such cases, the user needs to reproduce a creative work not for its primary and original purpose (the symphony enthralls; the cartoon amuses; the letter communicates its author's views on a particular topic) but rather to achieve an understanding that is different from that which the original author intended or produced. ${ }^{21}$ Another defining characteristic of these cases is that what had been a message from creator to audience has become the object of another message. That is, the first work's prior existence is not merely a convenience that makes it possible for the later comer to save herself time and effort; rather, the prior existence of the reproduced work is an essential part of the message that the use seeks to convey. ${ }^{22}$

This second characteristic-that a creative work used factually not only serves purposes different from the original but also makes reference to the fact of the original's existence-distinguishes factual uses both from uses that would substitute for the author's own work, and from other varieties of nonsubstitutionary use. Thus, for example, that a rock tune is reproduced for a different purpose (for example, someone prints its score interwoven with flowers for use as a wallpaper design) would not mean that the tune is being used as a fact. True, the difference in function may be relevant to whether the wallpaper should be given fair use treatment, ${ }^{23}$ but a use's factual nature should be independently recognized as relevant. Only if the later work points to the first work-as a musical composition might, for example, "quote" from a prior tune in a way that audiences are intended to recognize as quotationcould it be said that the later work is using the original as a fact. To put the claim somewhat differently: when the fact that the first work exists is an essential prerequisite for the second author's point to be made, then the special policies in favor of allowing free use of facts should come into play. ${ }^{24}$

world. See West Publishing Co. v Mead Data Central, Inc., 799 F2d 1219 (8th Cir 1986) (Mead Data's LEXIS service held to have infringed West's copyright when LEXIS gave its on-line users jump cites indicating where material in the interior of judicial opinions could be found in West reporters).

21. For an extreme example, consider Jorge Luis Borges, Pierre Menard, Author of the Quixote, in Donald A. Yates \& James E. Irby, ed, Labyrinths: Selected Stories Eo Other Writings 36, 43 (New Directions, 1964) (A modern author's production of the Quixote differs from Cervantes' Quixote, Borges tells us, even though the words used by both are the same.).

22. Thus, the musicologist had the students study this particular score because it brought about a revolution in music; the evangelist had the cartoon reprinted for the purpose of making a point about its original publication; the satirist would not have used characters from a movie neither she nor others had seen; the scholar quoted from a case and provided cites to it because it had been decided; and, as to the biography, the subject's choice of words can reveal a truth about the subject. In all these cases, the person reproducing the work was motivated in part by the fact that the work reproduced already existed in a particular context, and that context remains an important part of the object her message addresses.

23. The Nimmer treatise has argued that fair use may be favored when a "defendant's work .. . performs a different function than that of the plaintiff's." 3 Nimmer on Copyright $\$ 13.05[B]$ at 13$\mathbf{8 8 . 2 0}$ (cited in note 7). Works that use predecessor creations as fact may have different functions than the originals, and could deserve some shelter on that account, but the instant article argues that difference in function should not be the only reason they deserve solicitude.

24. I cannot deny there are cases where ordinary copying overlaps with factual use. After all, a photograph of Mount Rushmore in a guidebook serves two purposes: it is interesting to look at for 
Using prior works "as facts" may sound esoteric, but it is something that artists do, and that their lawyers recognize. For example, a lawyer whose firm represents rap artists and record companies argued recently that

[a] comedian parodying something pre-existing-a book, a movie, or someone's lifehas got to make a reference to it for the parody to work. If copyright law prevented that, it would be destroying a form of creative art and that would not be in keeping with the purpose of the copyright law. The same principle applies to the way certain rap composers intentionally refer to prior recordings. There is always going to be a difference between that form of reference, which has its own musical purpose, and outright piracy, the purpose of which is simply to steal someone's work and make money off it. ${ }^{25}$

\section{III}

\section{The Fate of Art/Facts in the Law}

When artists recreate other artists' works as facts, the creative works employed in this fashion constitute a species of Facts 1 ; they are "facts in the world." But because these facts are so clearly a product of special human creation, they deserve their own designation; let us call them art/facts, or Facts $_{\text {la }}$.

The existence of Facts la $_{\text {a }}$ should have been no surprise to copyright law. After all, the law of evidence applies as much to copyright trials as to other kinds of litigation, and the Federal Rules of Evidence have long recognized that communicative utterances can function as fact. The same testimony about a prior utterance that is hearsay and presumptively inadmissible as a reflection of what someone said occurred can, in another context, be admitted as a reflection of what was said (when the statement itself is the relevant occurrence). ${ }^{26} \mathrm{~A}$ jury is generally entitled to make conclusions about "facts in the world" from testimony by any person who directly witnessed them, and the fact that someone said a particular sequence of syllables-a Fact $_{1 \mathrm{a}}$-is no exception.

its own sake (an ordinary copyright purpose), and it shows the traveler what she will find-a certain point of interest-if she takes a certain route. It is only the second purpose which is factual. But the difficulty of handling such mixed cases should not prevent us from recognizing their existence, or the distinctly different issues their several components entail.

25. Sheila Rule, Record Companies are Challenging "Sampling" in Rap, NY Times C13 col 5 (April 21 , 1992) (quoting Ken Anderson).

26. See rule FRE 801(c): "Hearsay is a statement ... offered in evidence to prove the truth of the matter asserted." Testimony regarding prior statements given for other purposes is not hearsay.

Thus, sometimes litigants seek to have testimony on prior utterances admitted as evidence to prove the truth of whatever had been said. For example, a party who wants to prove that a fire destroyed missing files might want to introduce a witness, Jane Smith, who wishes to say, "Last April 15 , Jonathan phoned and told me, 'There's a fire going on in the branch office." "In such a case, the prior statement by Jonathan is being submitted as a Fact ${ }_{2}$ reflection of what Jonathan said occurred. Since Jonathan is not present in the courtroom for his credibility to be assessed, however, the reliability of the Fact $_{2}$ representation is questionable, and the hearsay rules apply. But the law also recognizes that sometimes prior utterances are submitted only to show that the utterance (a fact) occurred, and such testimony is treated differently. The reliability of a statement by a witness that she heard particular syllables uttered can be tested by the jury's observations on the witness's demeanor. So if Smith wants to testify to Jonathan's statement simply to explain why she was away 
But though evidence law is ready to admit that an utterance originally intended as a communication can later function as a fact, copyright law has trouble with that notion. For example, Judge Pierre Leval has argued that when a scholar writes about a human subject, often "the subject's very words ... a are the facts"; 27 he argues that when biographers quote a subject's unpublished letters or diaries without permission of the copyright holder, this consideration may warrant giving appropriate quotations the shelter of the fair use doctrine. ${ }^{28}$ However, his attempts in two cases to implement this view have been emphatically rejected. ${ }^{29}$ (Judge Leval has since described those cases as placing him "at the cutting edge of the law . . in the role of a salami."30)

Some progress has been made on the question of biographers' freedom to quote, ${ }^{31}$ but the larger issue remains unsettled. When an artist sends an artifact into the world, it affects other people and becomes part of their reality. To depict their reality accurately, and deal with the power others' images would otherwise have over them, audiences may need to reproduce artifacts in which copyright subsists. This need is legitimate. In the flagburning context, the Supreme Court has recognized that people who are affected by symbols created by others may have a right to use and even misuse

from her desk that day-that she had received a message which, whether it turned out to be accurate or not, gave her a reason to hurry to the branch office-it is not hearsay.

In both cases, the proffered testimony is a Fact ${ }_{2}$ reflection of reality. In the first context, Smith is an unreliable guide to the relevant Fact 1 (was there a fire?), while in the second Smith is a reliable

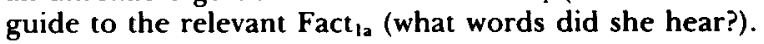

For an interesting illustration of the ways that hearsay/nonhearsay distinction can play out in a real trial, see George P. Fletcher, A Crime of Self-Defense: Bernhard Goetz and the Law on Trial 145-48 (U Chicago Press, 1988).

27. Pierre N. Leval, Fair Use or Foul? The Nineteenth Donald C. Brace Memorial Lecture, $36 \mathrm{~J}$ Copyright Society of USA 167, 171 (1989). "[T]he fact on which the biographer/critic comments is the protected expression. ... The words are the 'facts' that support the conclusion ... . The objective of fair use demands that [such instances] come within its scope ...." Id (emphasis in original). New Era Publications Inll v Henry Holt $\mho^{C}$ Co. 695 F Supp 1493, 1503 (SDNY 1988), aff'd on other grounds, 873 F2d 576 (2d Cir 1989).

28. See Pierre N. Leval, Toward a Fair Use Standard, 103 Harv L Rev 1105 , 1113 (1990) ("[Q]uotation [is] a tool of accurate historical method."). I do not concur with all of Judge Leval's views on the subject; I find particularly troubling his position on the role of motive. See notes 34 \& 50 and accompanying text.

29. The first case involved the letters of J. D. Salinger. Salinger $v$ Random House, Inc., $650 \mathrm{~F}$ Supp 413, 424 (SDNY 1986) (preliminary injunction denied) (the "fact" issue appears here by implication), rev'd, 811 F2d 90, 96 (2d Cir 1987). (The Second Circuit, in reversing, asserted that a biographer loses little by being required to use "words of his own choosing" instead of his subject's words.) The second case involved the unpublished work of $L$. Ron Hubbard, founder of the Church of Scientology. New Era Pub. Intl v Henry Holt E' Co., 695 F Supp 1493, 1504 (SDNY 1988), aff'd on other grounds, 873 F2d 576 (2d Cir 1989).

One treatise writer argues that "[n]o court has ever held that the public has a right to know expression." William F. Patry, The Fair Use Privilege in Copyright Law 466 (Bureau Natl Affairs, 1985) (citations omitted).

30. Leval, $36 \mathrm{~J}$ Copyright Society of USA at 168 (cited in note 27 ).

31. See Wright $v$ Warner Books, 748 F Supp 105 (SDNY 1990), aff'd, 953 F2d 731 (2d Cir 1991) (biographer of Richard Wright permitted to include some quotations from unpublished work); see also the concurring opinion of Chief Judge Oakes in New Era, 873 F2d at 592. For legislative developments, see Jessica Litman, Copyright and Information Policy, 55 L \& Contemp Probs 185 (Spring 1992). 
those symbols in pursuit of their own self-expression. ${ }^{32}$ But in the copyright context, Feist seems to declare that "facts" are uncreated things; how then will the courts be able to understand claims that sometimes an author's creative works become "facts" with which others must deal, and that fair use should accommodate this need?

The assumption that "facts" and "created works" are mutually exclusive categories led, luckily, to a proper result in Feist: denying copyright protection to a telephone book's nonselective and uncreatively arranged

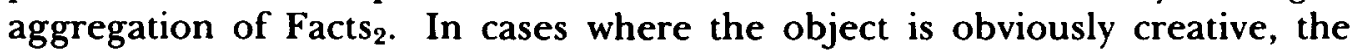
same spurious need to choose a single category can lead to overprotection of Facts $_{1 \mathrm{a}}$. The latter result is very troubling. For example, consider a biography that uses portions of its subject's letters to substantiate a thesis about the subject's motives. If the biography's subject does not like the way he is portrayed, he may be able to use copyright to restrain the biographer's use of needed evidence. In short, the overprotection of art/facts enables private censors to disable their critics and hamper accurate discussion. ${ }^{33}$ The Feist epistemological error can have serious free speech consequences.

\section{IV}

\section{Bases for a Public Entitlement to Copy}

Of the many arguments that can be made to defend giving the public the liberty to use others' created works as Facts la $_{\text {, }}$ let me present briefly two, both of which apply to users operating out of motives that are not purely pecuniary. ${ }^{34}$ The first is a proposition built on a substantive notion of minimum entitlement; the second is built on a conception of equality.

Both arguments begin with a recognition that much of the modern environment is a product of deliberate human creation-our world is constituted more by buildings and landscape architecture than by natural woods and water-and that art will address as its object much that is itself art. This is obvious when one considers the painting of cityscapes, the performance of parodies, or much of the art known as post-modern. ${ }^{35}$ The

32. Texas $v$ Johnson, 491 US 397, 403-06 (1989). See the discussion of audiences' moral rights in Gordon, 57 U Chi L Rev at 1032-37, 1043-46 (cited in note 16).

33. See Gordon, $57 \mathrm{U}$ Chi L Rev at 1032-49 (cited in note 16) (discussing economic and philosophic approaches to the problem of private censorship).

34. Thus I disagree with Judge Leval's position that motive should be irrelevant. See Leval, 103 Harv L Rev at 1126-28 (cited in note 28). Note also that the entitlements I address would be irrelevant to the Feist case itself, where the defendant's motives appear to have been purely pecuniary. That case could have been decided simply on statutory grounds-that the Copyright Act gives no protection to compilations that are uncreatively selected, organized, and arranged.

On the difficult issue of distinguishing pecuniary from nonpecuniary motives, see Gordon, $A$ Property Right in Self Expression (cited in note 15), where all this is discussed in more depth.

35. "The referent in post-Modern art is no longer 'nature' but the closed system of fabricated signs that make up our environment." John Carlin, Culture Vultures: Artistic Appropriation and Intellectual Property Law, 13 Colum-VLA J L \& Arts 103, 111 (1988); see also id at 106-11, 126-40. 
use of prior art as object is less obvious yet nevertheless present in virtually all writing. ${ }^{36}$

When use of a predecessor's art includes substantial detail, a collision may occur between copyright and the second author's desire to depict accurately the forces of which her world consists. The artifact that began as pure creation is now a fact of life.

\section{A. A Substantive Entitlement to Self-Expression}

A substantive entitlement to use such art/facts could be grounded in a conception of human nature that places fundamental importance on the freedom to discuss, recast and transform the aspects of the world that influence the structures of one's mind. This is not the place to sketch such a theory (if I am ever able to do so fully), but its overall structure is fairly clear: one would need to argue that the freedom to recast one's reality-to "name" the phenomena of one's universe, as Adam is said to have done-is as essential to what it means to be human as are the freedoms we now hold to be fundamental and immune from governmental interference. ${ }^{97}$ Such an argument should strike most of us, raised in a first amendment tradition, as reasonable in its broad outlines, if difficult to implement in particular cases.

A writer must be free to write about the effect of earlier writers upon her. An unencumbered freedom to attempt to describe and give meaning to reality would seem to be a birthright which every potential artist should be granted, free of the fear of being "checkmated"38 by predecessors.

In a civilized nation, much of reality is artifact. Too broad a set of intellectual property rights can give one set of persons control over how that reality is viewed, perceived, interpreted-control over what the world means. Such control casts a pall over those acts of understanding that are at the core of what it means to be human. To the extent that human need can ever justify placing limitations on others' rights, ${ }^{39}$ limitations on copyright are appropriate to provide the public a liberty of reconceptualization.

36. On the latter, consider the views of Harold Bloom, The Anxiely of Influence: A Theory of Poetry (Oxford U Press, 1973); see also Gordon, $57 \mathrm{U}$ Chi L Rev at 1028-32 (cited in note 16).

37. That copyright and other forms of property are forms of governmental action that restrict the freedom of non-owners should by now be clear. See, for example, New York Times v Sullivan, 376 US 967 (1964) (state libel law constitutes state action; first and fourteenth amendments apply). For a discussion applying this legal realist insight to the copyright context, see Wendy J. Gordon, $A n$ Inquiry into the Merits of Copyright: The Challenges of Consistency, Consent and Encouragement Theory, 41 Stan L Rev 1343, 1422-25 (1989). Many commentators have therefore argued that the first amendment should provide some protection for copyright defendants even beyond the fair use doctrine.

The entitlements argued for in this article have obvious first amendment overtones. Nevertheless, they are offered here as independently-based policy arguments.

38. Courts have proved somewhat sensitive to the need to avoid giving a copyright that might "checkmate" a subsequent creator from making full use of public domain ideas. See, for example, Morrissey $v$ Proctor E Gamble Co., 379 F2d 675 (1st Cir 1967) (copyright denied in statement of contest rules lest the substance of the contest be monopolized).

39. For exploration of certain need-based entitlements in intellectual property, see Gordon, 41 Stan L Rev at 1460-62 (cited in note 37). Admittedly, self-expression is rarely as exigent a need as is food and shelter, but note that the cost of allowing self-expression is rarely as high as the cost of providing food and shelter. 
One advocate of the importance of this liberty is Salman Rushdie, whose reconceptions have put his life at risk. In a recent speech, Rushdie noted that "the row over The Satanic Verses was at bottom an argument about who should have power over the grand narrative, the Story of Islam, and that that power must belong equally to everyone." 40 As he argued: "Those who do not have power over the story that dominates their lives, power to retell it, rethink it, deconstruct it, joke about it, and change it as times change, truly are powerless, because they cannot think new thoughts." 4 Copyright should be wary of impairing that power.

One might oppose my first argument for a public entitlement on the ground that copyright's incentive structure may in the future provide new intellectual products in exchange for enforced silence today, so that (perhaps) the public's long-run interest in comprehending the world will be furthered rather than hampered by limiting the public's ability to use others' works today. ${ }^{42}$ But not all information is fungible, and restraint cannot always be compensated for by riches. ${ }^{43}$ The liberty to reconceive the dominant images of one's time and to exhibit the self-respect of making that reconception public ${ }^{44}$ is not something that has easy substitutes.

One might alternatively oppose my first argument on the ground that it is awkwardly dependent upon controversial notions of human nature and of the relationship between "need" and "right." Those are more difficult charges to address even in summary form here. ${ }^{45}$ Instead, let us shift to a second and possibly more tractable way to defend the public's right to use Facts ${ }_{1 \mathrm{a}}$ : an appeal to intergenerational equity.

\section{B. An Equality-Based Entitlement to Depict Reality}

One might condition the enforcement of copyright on the preservation of an equality between early and later authors. The desire to preserve such an equality arguably operates in John Locke's labor theory of property, for Locke's theory includes a proviso that private property should not arise unless

40. Lessons, Harsh and Diffcult from 1,000 Days "Trapped Inside a Metaphor," NY Times B8 (Dec 12, 1991) (excerpts from Rushdie's address).

41. Id.

42. Thus, in Harper E Row Publishers, Inc. $v$. The Nation, 471 US 539, 558 (1985), the Court, in rejecting a first amendment defense, reasoned that copyright is itself an "engine of free expression."

43. Even if it could be empirically proven that the monetary value of a use foregone is smaller than the monetary value of future creations thereby induced, that showing should not be conclusive on the issue of whether the use should be prohibited. The first amendment is capable of condemning governmental regulation that promises social wealth; economic prosperity does not justify governmental activity that restrains free speech. Even independently of the first amendment, Congress and the courts are capable of making similar priority choices.

44. In some continental theory, property is seen as a way of making one's will concrete, and acting in the world through objects is seen as essential for personhood. See Margaret Jane Radin, Property and Personhood, 34 Stan L Rev 957, 961 n7, $971-78$ (1982). A property right in self-expression draws on similar justification.

45. For further development, see generally Gordon, A Property Right in Self Expression (cited in note 15 ). 
"enough, and as good" opportunities remain open to the non-propertied.46 Regardless of whether one follows Locke, an equality of starting points is an independently justifiable moral precondition to the grant of ownership rights.

There are common goals toward which many creative persons labor. ${ }^{47}$ "Describing reality" is one such widely-shared goal; an artist blocked by a prohibition against commenting about an aspect of reality is likely to be significantly worse off than earlier artists who were free of the effect of any such prohibition. A painter in the state of nature who wants to depict his reality paints trees and caves. A painter in Renaissance Venice who wishes to depict reality will not only paint trees, but also the gondolas and buildings that others' fancy has created. When the age of modern copyright first arrives, a painter will be free to depict what came before; she should not, by exercising that liberty, close it off from others.

Creators labor to answer a set of questions; to have any answer taken out of their grasp because another creator has staked a property claim in some part of the information needed to reach the answer would seem to give the first creator an unjustified right to harm the second. That a first creator has labored is not sufficient ground to justify giving her a right to keep others from achieving their proper goals. As Locke notes, his labor theory of property does not justify imposing restrictions on the "industry" 48 of later comers; as Mill suggests, an ideal community would place great emphasis on securing for its citizens the "unfettered use and disposal of [their] . . . mental faculties." 49 Whenever a user seeks to copy the first creator's work not to "save himself Pains,"50 but rather to accomplish some other more general goal, there is the possibility that assertion of a property right against him will make him less able to utilize his faculties than were his predecessors.

One implication of so guaranteeing equality among authorial starting points is that artists who had available for depiction on their canvases all their surroundings should have only limited entitlements to bar the replication of surroundings they create, and that in turn a second generation should not have unlimited power to bar a third from such replication. ${ }^{51}$ Again it might be argued against my position that granting earlier authors broad rights to bar

46. John Locke, Second Treatise of Government, in Peter Laslett, ed, Two Treatises of Government ch V, $\S 27$ (Cambridge U Press, 1988). For a fuller exploration of the free speech implications of the Lockean proviso that "enough, and as good" be left, see Gordon, A Property Right in Self Expression (cited in note 15); for a briefer summary, see Gordon, 41 Stan L Rev at 1459-65 (cited in note 37). For a different perspective on the proviso, see Justin Hughes, The Philosophy of Intellectual Property, 77 Geo L J 287 (1988).

47. The word "common" is being used here in two senses: the goals are "common" in the sense of shared, and "common" in the sense of frequently occurring. In addition, such goals are in part formed by the overall artistic heritage, which we all own in common.

48. See Locke, Second Treatise of Government ch V, \& 34 (cited in note 46).

49. John Stuart Mill, Of Property, in C. B. MacPherson, ed, Property: Mainstream and Critical Positions 78 (U Toronto Press, 1978). Mill seems to have presumed that such an unfettered privilege of expression would be part of what an ideal community, unhampered by any history of previous possession, would adopt.

50. Locke, Second Treatise of Government ch V, $\$ 34$ (cited in note 46).

51. Thus an artist should not have an unlimited right to bar a later comer from placing on canvas some version of the predecessor's painting that hangs-perhaps as a cheap print behind a 
copying may generate benefits for later authors in terms of both monetary benefit and a richer cultural heritage; again I respond that not all goods are fungible.

\section{Comments on Implementation}

I do not mean to argue that using a copyrighted work as a Fact 1 justifies automatic immunity from infringement suits. ${ }^{52}$ That prospect properly seems to have worried the Supreme Court. ${ }^{53}$ What I do contend is that a work's being employed as a Fact $_{1 \mathrm{a}}$ justifies treatment different in kind from that given other kinds of uses.

human model's head-on the successor's kitchen wall, so long as the successor's motive is to picture the influences on his life rather than merely to profit from the original's efforts.

52. Nor is such per se immunity supported by my prior work. There I have suggested that the presence of nonmonetizable interests (such as the public's interest in fact) could constitute a market failure for which fair use treatment is appropriate. See Wendy J. Gordon, Fair Use as Market Failure: A Structural and Economic Analysis of the Betamax Case and its Predecessors, 82 Colum L Rev 1600, 1630-32 (1982). But market failure constitutes only one prong of that fair use inquiry; for the defendant to obtain free use, that article suggested, there should also be, inter alia, no substantial injury to incentives, id at 1614-22, and there should be no alternative avenues (such as a judicially imposed compulsory license) through which the use could go forward, id at 1622-24.

To give all factual uses automatic immunity could undermine copyright incentives, for, as illustrated by the Mount Rushmore guidebook example, see note 24, uses that mix fact and enjoyment abound. As for alternative avenues, the notion of denying injunctions yet imposing monetary relief is becoming more acceptable to judges handling copyright cases. Compare the discussion and sources cited in id at 1622-24 with Hon. James L. Oakes, Copyrights and Copyremedies: Unfair Use and Injunctions, 18 Hofstra L Rev 983 (1990) (suggesting that in some cases monetary relief might be granted and injunctive relief denied). Thus my market failure approach would not dictate free use for all fact uses.

It should also be noted that if my market failure approach were taken as exclusive-which it should not be, see Gordon, 82 Colum L Rev at 1601 (cited in this note)-it could actually result in too few fact uses being treated as fair use; that is because the market failure analysis was crafted for the purpose of identifying those contexts in which fair use will be economically justifiable. To the extent that our law recognized the entitlements sketched in the instant article as trumping economic interests, those entitlements would justify treating some fact uses as "fair" regardless of the effect on economic incentives.

53. It was largely the prospect of automatic immunity that led the Supreme Court in the pre-Feist Harper $\mathcal{G}^{2}$ Row case to reject the suggestion that fair use attached to the factual use of creative expression. Nation Enterprises claimed it had the right to quote a former president's unpublished memoirs in a magazine article because, inter alia, "the precise manner in which [he] expressed himself [was] as newsworthy as what he had to say." "Harper $E$ Row, Inc. $v$ Nation Enterprises, 471 US 539,556 (1985). The Court implicitly declined to give the president's form of expression the same treatment as the facts he expressed; the Court argued that the defendant's approach "would expand fair use to effectively destroy any expectation of copyright protection in the work of a public figure." Id at $\mathbf{5 5 7}$.

If the issue were understood not as a matter of giving fact uses the same treatment as ordinary facts, but rather of giving some deference to such uses' factual nature, the Court might respond differently; among other things, the impact on incentives would not be so great as the Court imagined in Harper $\mathcal{E}$ Row. See id at 557-60.

Also, in Harper $\mathcal{E}$ Row the Court seemed to disbelieve the defendant's claims about the president's expression itself being newsworthy. See id at 561 (suggesting that The Nation magazine had sought to make its infringement news). In a case where the factual character of a defendant's use is clearer than it was in the Harper $\mathcal{E}$ Row matter, the Court might react more sympathetically to a claim that factual use should be weighted in defendant's favor as part of the fair use calculus. One of the four non-exclusive factors to be considered in fair-use cases is the "purpose and character of the use." 17 USC $\S 107$ (1). 
Elsewhere I offer proposals for how the law should deal with cases involving art/facts; as part of the analysis there, I erect some dividing lines and suggest that even authors who recreate predecessors' work for the sake of depicting reality might sometimes be fairly required to pay for the privilege. ${ }^{54}$ I also acknowledge that there may even be rare cases when it is appropriate to enjoin the use of an art/fact; when, for example, the use of an art/fact does not serve the purposes these entitlements are intended to safeguard, and no other consideration is operable, an injunction may be a fitting response. ${ }^{55}$ The purpose of the instant article, however, is not to address issues of implementation, but rather to make clear the existence of a significant class of uses that employ created works as fact, to suggest why the law should develop special rules for the treatment of such uses, and to underline that freedom for facts should not depend on their putatively "uncreated" status.

54. See Gordon, A Property Right in Self Expression at Part II, $\$ 4$ (cited in note 15) (suggesting that those who reap monetary profit from the labors of others can be fairly required to pay out a portion of that profit even where the users' motives-for example, to describe reality-are sufficient to make it inappropriate to enjoin the use).

55. Consider, for example, the case of Educational Testing Services $v$. Katzman, 793 F2d 533 (3d Cir 1986). The defendant who ran an SAT/achievement test review course presumably was using the ETS questions not primarily because they were expressed well or organized powerfully or for any of the other considerations we tend to associate with a grant of copyright. His primary motive for copying them was, surely, because they were there-like Everest. He was showing the students the ETS questions as a geographer might instruct his students that a particular set of mountains, with

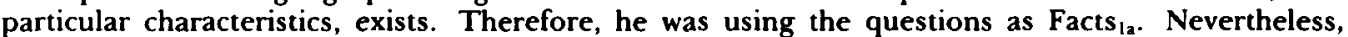
allowing this $\mathrm{Fact}_{1 \mathrm{a}}$ use might over time erode the accuracy of the tests as a method of fairly measuring student abilities. Of course, it might be argued that ETS could simply make new questions each time. But test development might require a certain amount of re-use of questions (to test their ability to measure the characteristics at issue); if so, allowing review courses to give their clientele actual SAT questions could leave ETS with an undesirable choice between two kinds of inaccuracy: the inaccuracy that comes from some students having an edge others do not, or the inaccuracy that comes from inadequate pre-testing of a question. In such a case, the public may indeed be ill served by allowing duplication of the test questions.

By itself, this calculation of public benefit should not be conclusive. I have cautioned against making tradeoffs that would, for an arguable gain in overall utility, sacrifice a liberty of use protected by one of the two entitlements sketched above. See for example text at notes 42-44. However, not all fact uses are protected by those two entitlements, and it is hard to see the SAT tutors' use falling into a protected category.

As for the substantive entitlement, it was crafted to give people the liberty they need to reconceptualize their world; to the extent that neither the SAT tutors nor their students want access to test questions for such a purpose, the argued-for substantive entitlement would not assist them. As for the equality-based entitlement to copy, it was crafted to give different generations of creators equivalent opportunities, and it too appears inapplicable: ETS in creating the work was not doing something that it now seeks to prevent others from doing. Further, the SAT tutors want the ability to copy test questions for a reason rooted in inequality: to provide their students a comparative advantage. (If everyone had access to the test questions, the tutored students would gain little from the access.)

For these reasons, an injunction might be appropriate against the tutors' Fact $_{{ }_{1}}$ use. This conclusion must be tentative, however, for the two entitlements presented here are urged to be sufficient but not necessary justifications for the public's having a right against injunctions, and other sufficient grounds of course exist. 


\section{Conclusion}

Whether or not one agrees with the Supreme Court that a phone book compiler "discovers" rather than "creates" the bare data his book provides, there are some facts-like the face of Mount Rushmore-that everyone will admit were the product of deliberate creation. The Court in Feist therefore made a significant epistemological and doctrinal error when it insisted that facts were incapable of being created. After all, much of our world is simultaneously creation and fact. 